\title{
Human rights, cosmopolitanism and utopias: implications for citizenship education
}

\section{Hugh Starkey}

\section{Institute of Education, University of London}

\begin{abstract}
Citizenship education, defined as learning to live together, requires agreement on certain common principles. One central purpose of a state education system is the transmission of common normative standards such as the human rights and fundamental freedoms that underpin liberal democratic societies. The paper identifies the conceptual roots of the Universal Declaration of Human Rights (UDHR) in the sociological concept of utopia and Enlightenment cosmopolitanism. In the UDHR, the vision of freedoms that may promote human flourishing provides a precise way of conceptualising limits on state power. Whilst human rights is not a general theory, the concept has the hugely beneficial property of enabling people whose value systems are diverse and apparently incompatible, nonetheless to recognise and accept common standards and principles that make living in society possible. The implications of this are that human rights education is rightfully recognised as an essential component of citizenship education.
\end{abstract}

\section{Keywords}

Human rights, cosmopolitanism, utopia, citizenship, education, democracy

Education for citizenship has been introduced in education systems across the world as a response to a number of perceived tensions in contemporary societies, particularly those resulting from migration and changing demographics as threats from violent extremist political movements. These essentially political struggles result from tensions between the local and the global; tradition and modernity; competition and equality; the material and the spiritual (Delors, 1996). At a global level, the persistence of violent conflicts has been characterised as stemming from a clash of civilisations (Huntington, 1996). As sociologists raise the ultimate question of whether human beings can in fact live together or whether cultures and prevailing modes of thought make peaceful co-existence within and between nation states an impossible dream (Touraine, [1997] 2000), educators must grapple with the issue of learning to live together.

In a globalising world, any educational response to perceived social fractures requires a global frame of reference. In this paper I identify theoretical work on utopias and 
cosmopolitanism as having considerable relevance for education in general and citizenship education in particular. I explore the implications for citizenship education of the fundamental tenet of liberal democracy that living together requires agreement on certain common principles and procedural values and that these principles therefore need to be transmitted through and by the education system.

This article is based on a detailed textual analysis of the Universal Declaration of Human Rights (UDHR) (United Nations General Assembly, 1948) and an examination of its historical context. I propose that it can be read as a text that is cosmopolitan in perspective, utopian in intention and universal in its potential to enable people whose value systems are diverse and apparently incompatible, nonetheless to recognise and accept common standards and principles that make living in society possible. The implications of this are that human rights education is rightfully an essential component of citizenship education.

\section{Citizenship education as a response to tensions}

Migration on a global scale brings together populations with very different world views and social practices. At a local level manifestations of intolerance and discrimination frequently lead to tensions and sometimes violence on a scale sufficient to start to undermine confidence in democracy and human rights as the basis for the social contract. Responding to concerns by governments to real and perceived threats to social cohesion across Europe, the Council of Europe commissioned a group of distinguished academic and political figures to report on the challenges arising from the resurgence of intolerance and discrimination in Europe. The group identified developments in European society that challenge any assumption that there is consensus around the principles of democracy and human rights. As well as rising intolerance, manifested in support for xenophobic and populist parties, the report highlights concerning levels of discrimination as well as 'parallel societies; Islamic 
extremism; loss of democratic freedoms; and a possible clash between "religious freedom" and freedom of expression' (Group of Eminent Persons, 2011:5). The report identifies the root of the issue of living together in a liberal democracy as the need to reconcile diversity and freedoms. In the report's recommendations, educators are given an essential role in transmitting 'the norms and values that form the binding element in the functioning of society' (GEP, 2011: 37). This refers to the importance of a common understanding of the universal human rights standards embodied in the European Convention on Human Rights.

This emphasis on the role of education as contributing to social cohesion follows an earlier report by an equally distinguished commission, convened by UNESCO, which proposed learning to live together as one of four pillars of education. This is defined in terms of a cosmopolitan perspective that envisages all people gradually acknowledging an identity as global citizen in addition to local and national feelings of belonging. The Commission articulated the conviction that education has the capacity to encourage attempts 'to attain the ideals of peace, freedom and social justice'. In this sense, education is a 'necessary utopia' (Delors, 1996: 13). I will explore later in this article the potential of the sociological concept of utopia to drive struggles for social justice and confront intolerance and violence.

Whilst major international reports identify education in general as a response to tensions in liberal and democratic societies, citizenship education is a particular site where the political nature of these conflicts can be specifically acknowledged, debated and addressed (Osler \& Starkey, 2005). In England as in many countries, citizenship education has been acknowledged as providing an opportunity to discuss challenges for the world such as the continuing inequality of extreme poverty, predominantly in the global south, but also in neighbourhoods of ostensibly rich cities in the north (DfES, 2005). Young people can at least be made aware of ways in which such injustice fuels conflicts and is a source of destabilisation for global systems that are interdependent and fragile. 
There is also concern in a number of democratic nation-states about levels of political engagement, particularly among the young. Citizenship education has been introduced in an attempt to help young people to understand democracy and engage with democratic processes. However, alongside a concern for the perceived apathy of youth there is a concern that youth may pose a threat to society by their participation in violent or anti-social behaviour. Citizenship education is in this case intended as a means of socialising young people (QCA, 1998; Kerr, 1999).

In Europe, where there is a historical consciousness of the legacy of Fascism, there are concerns about the growth of anti-democratic and racist movements that may appeal to young people and threaten democracy (GEP, 2011; Goodwin, 2011). This issue has also been addressed in England in a government-funded research report that gives considerable prominence to the importance of United Nations human rights instruments as providing standards for living together both within schools and in the wider society (Bonnell, J., Copestake, P., Kerr, D., Passy, R., Reed, C., Salter, R., et al.,2011). European education ministers have agreed on the need to challenge-such anti-democratic movements and attitudes and promote antiracism (Council of Europe, 2002). Since the attacks on New York and Washington on 11 September 2001, democratic governments have seen citizenship education as a site for combatting the nihilistic, fatalistic and deterministic propaganda of al-Qaeda. This co-option of citizenship education as part of a strategy to prevent terrorism was articulated by ministers in the UK from 2001 and the bombings in London in 2005 provoked a review of the curriculum to ensure that issues of diversity and identity were made central to eitizenship education (DfES, 2007; Osler, 2008).

A controversial aspect of citizenship education is the extent to which its curriculum addresses the issue of diversity and freedoms. There is an intellectual and political tension within multicultural democracies concerning the need to promote national unity or cohesion 
and the need to accommodate, and indeed support, a range of cultural communities within the nation-state (Taylor, 1994; Runnymede Trust, 2000). In England, New Labour governments (1997-2010) identified citizenship education as a means to encourage valuing diversity and countering racism, initially in a formal response to the recommendations of the Stephen Lawrence Inquiry (Home Office, 1999). The 2005 London bombings provided the impetus for a further a review of the citizenship curriculum to ensure detailed attention to issues of identity and diversity and living together (DfES, 2007). This was reinforced by a duty on schools to promote 'community cohesion', a concept introduced in a report on responses to urban violence (Home Office, 2001). However, in 2010 and early 2011, in what may be construed as a concerted response to these tensions from Conservative heads of government of France, Germany and the UK, multiculturalism was denounced as a failure (GEP, 2011) with the implication that citizenship education should emphasise an essentially homogenous national identity. From whatever perspective, citizenship education is nevertheless one intervention available to the State for the purpose of addressing destabilising fractures in society.

A common thread running through these reasons for including citizenship education is a requirement for a global perspective, since globalisation is the context that explains the unsettling changes to which societies are subject (Osler, 2006). A second common thread is the need to transmit normative principles, particularly commitments to democracy as the means of providing governance in diverse societies. An International Consensus Panel convened by James Banks, director of the Center for Multicultural Education, University of Washington Seattle, was set up to attempt to produce guidelines that would be relevant across the world. The panel recommended that:

Increased diversity and increased recognition of diversity require a vigorous reexamination of the ends and means of citizenship education. Multicultural societies are 
faced with the problem of creating nation-states that recognize and incorporate the diversity of their citizens and embrace an overarching set of shared values, ideals, and goals to which all citizens are committed. (Banks et al., 2005: 7).

The 'ideals and goals' for a multicultural society are a utopian perspective. However, utopian visions can lead to disastrous consequences and must be treated with extreme caution. This article argues that the Universal Declaration of Human Rights has the capacity to provide both a utopian vision and a set of standards and principles based on equality and diversity. The principles can command consensus as to their moral force even when there may be disagreements as to the reasons why people are prepared to accept them.

\section{Utopia and cosmopolitanism}

Utopian visions characterised some of the most appalling political regimes of the twentieth century. Among these, Hitler, Stalin, Mao and Pol Pot governed on the basis that they had a vision of a better world. These 'failed utopias' (Klug, 2000: 189) nonetheless inspired other contrasting visions, based not on superiority of race or class but on the notion of human dignity and equality of rights. Alongside what the historian Jay Winter (2006) calls the disastrous major utopias were a number of minor utopias, attempts at specific periods of time to create new cultures and consciousness based on cosmopolitan perspectives and visions of human rights.

Amongst educationalists there is a current of sociological theory that promotes utopian imaginings as having the capacity to raise educational debate from post-modern discourses of cynicism and indecision and inspire hope rather than despair. Utopian thinking is recommended for educational leadership and management (Halpin, 2003, 2006; Webb, 2009). It encourages imaginative reconceptualisation of schools as sites of deliberative democracy, both in governance and in pedagogy. It lifts the vision of the curriculum above the basic prescribed programmes of study. Utopia requires and encourages imagination. The 
process of imagining utopia challenges taken for granted assumptions and suggests alternatives. It is the utopia that 'introduces a sense of doubt that shatters the obvious' Ricoeur (1978: 19).

The sociological concept of utopia has been theorised as a driving force motivating humans to exercise agency and shape history (Mannheim, [1936] 1991). Politically, utopian perspectives may challenge unequal social and economic conditions, for example. Utopia as possibility has been theorised by Giddens as 'utopian realism' (1990: 156) and by Rawls as 'realistic utopia' (1999: 128). Utopian realism is a space where life politics, based on freedom to create a fulfilling life, meets emancipatory politics. Personal fulfilment and human struggle for freedom from inequalities may coincide (Giddens, 1990). However, educationalists have a responsibility to provide the critical tools to interrupt utopias imagined by populist or religious extremists that may require indoctrination or physical coercion to achieve.

Critical theory, the sociological movement in education inspired by Paulo Freire, also engages strongly with ideas of utopia for instance in addressing the question, central to citizenship education, of the extent to which the school system really has the capacity to become an inclusive public sphere (Torres \& Teodoro, 2007). Utopia provides a tool for schools and school leaders to make decisions about future choices based on realistic evaluations of schools as social systems. Combining utopian vision and sociological insights school leaders can come to see 'not the face of the perfect (and inevitable) future, but the face of an alternative, better, and historically possible (but far from certain) future' (Wallerstein, 1998: 1-2). Utopia is the vision against which sociological realities can be judged. From this process political action may be engaged.

Cosmopolitanism is the Enlightenment philosophy associated notably with Immanuel Kant. It is based on a liberal conception of human beings as a single community in which all have equal entitlement to dignity and to fundamental freedoms. On this account human 
beings are 'instantiations of a universal humanity' (Beiner, 1995:2 original emphasis). The cosmopolitan perspective has much to offer educators in multicultural societies in a globalised age, since it is an ideal that 'combines a commitment to humanist principles and norms, an assumption of human equality, with a recognition of difference, and indeed a celebration of diversity' (Kaldor, 2003:19).

Given the global issues of extreme poverty, denial of rights and injustice, cosmopolitanism may appear to be a utopian perspective. In a previous period of mass migration, ethnic tension and war the American philosopher and educationalist John Dewey sought a conception of education and democracy that could unite students of different backgrounds. However, he came up against the dominance of nationalist thinking in education systems and noted how these had obliterated previous Enlightenment traditions based on cosmopolitanism. The development of nationalised education in the nineteenth century resulted in education becoming a civic function that was 'identified with the realization of the ideal of the national state. The "state" was substituted for humanity; cosmopolitanism gave way to nationalism'. (Dewey, [1916], 2002:108).

Dewey's analysis helps to explain the role of education in promoting nationalism as a dominant ideology throughout much of the twentieth century. In many circumstances cosmopolitanism has been presented as unpatriotic and as being in opposition to nationalism. In an extreme case, Jews in Nazi Germany were branded as enemies of the state because of their assumed commitment to cosmopolitanism. Citizenship education as a function of state education is still usually based on a nationalist paradigm. The hypothetical good citizen approaches the wider world from an essentially national perspective, knowing about national political institutions and traditions (Osler \& Starkey, 2009). However, such a conception has proved unsatisfactory in contexts of diverse multicultural societies and there is growing 
recognition that education for cosmopolitan citizenship offers a model more capable of engaging the full range of students.

At its most basic, the cosmopolitan citizen is one who 'views herself as a citizen of a world community based on common human values' (Anderson-Gold, 2001:1). This challenges purely nationalistic conceptions of citizenship that emphasise the primacy of the national community. It suggests that the notion of community can be extended so that its limiting case is a community composed of all human beings. Such a community can be envisaged within a religious or a humanist perspective.

\section{Human rights as utopian and cosmopolitan vision}

The Universal Declaration of Human Rights is a proclamation of a common set of standards, norms and principles that has huge moral force on the basis that these standards have been adopted voluntarily by all the governments of the world as well as by religious communities and civil society. As Donnelly points out, the proclaimed universality of human rights 'is more prescriptive than descriptive. The claim of "universal" human rights is that all human beings ought to be treated in these ways, not that they are or have been, or that these norms are (let alone have been) accepted everywhere' (2003: 2).

The Universal Declaration of Human Rights (UDHR) proposes a vision of freedom, justice and peace in the world. This is a vision of hope that may inspire the utopian imagination. International organisations promote human rights as a common universal standard that can guide the projects and actions of teachers and educators. However, in the UK, the political right has a record of opposition to the Human Rights Act, favouring instead a national Bill of Rights (Conservative Party, 2010) and this has led to misleading stories about ways in which human rights have been interpreted circulating in the press and in political speeches (Klug, 2011). On the other hand, there has been relatively little exploration 
of what a commitment to human rights actually includes (Osler \& Starkey, 2010). The following section, based on a close reading of the text of the Universal Declaration of Human Rights (UDHR), the foundational text from which all later human rights instruments derive, analyses it for its relevance to diversity and freedoms.

The Universal Declaration of Human Rights offers a vision and a promise. The vision of the new world order is proclaimed in the preamble to the UDHR. It can be read as a reaction to the background of wartime atrocities. The second paragraph of the preamble sets out a double case: 'disregard and contempt for human rights have resulted in barbarous acts which have outraged the conscience of mankind...' The reason for the Declaration is that humanity is shamed because 'barbarous acts' have been committed and such behaviour must be prevented in future. Those drafting the Declaration did not feel the need to specify the nature of the barbarity since it was of recent memory. It was assumed to be in the consciousness of those who read and heard it. In the preamble, barbarity is defined in terms of 'disregard and contempt for human rights'. In other words, this highly judgemental phrase proclaims that those who act in a way that denies human rights are liable to be considered barbarians, that is, uncivilised. Human rights are part of a struggle for civilisation against barbarity. The UDHR is an invitation to make moral judgements, particularly about the actions of governments and their agents such as the police and the military.

The basis for such moral judgements is conscience. The 'barbarous acts' are said to 'have outraged the conscience of mankind'. The drafters thus set themselves up as the guardians of the global conscience. It is conscience that enables human beings to distinguish between right and wrong, civilisation and barbarity. There is an assumption in the UDHR that there is a collective conscience that extends to the whole of humanity. This is highly speculative, since it was clearly the case that many well-educated citizens, who would have considered themselves to be civilised, participated in or supported war-time and pre-war 
atrocities. The UDHR is therefore asserting a new normative standard. Just as the main religious and humanist traditions aim to develop a conscience of good and evil, right and wrong in their followers, so the UDHR proposes the terms on which judgements of conscience can be made.

The concept of human rights offers an alternative standard of judgement to utilitarianism and scientific positivism. A utilitarian philosophy based on the greatest good for the greatest number has nothing to say about how minorities or the civilian populations of enemy states are treated. A misguided scientific view based on racial superiority is also likely to encourage assent to policies such as eugenics including forced sterilisation and indeed the so-called final solution of genocide. Human rights are proposed as an alternative moral philosophical perspective, one that takes into consideration the well-being of every individual.

The preamble of the UDHR looks back and looks forward. It is explicitly a reaction to the 'barbarous acts' perpetrated in the recent past. It also sets out a vision for the future. In fact this future-oriented perspective is given absolute priority as the first element of the Declaration:

Whereas recognition of the inherent dignity and of the equal and inalienable rights of all members of the human family is the foundation of freedom, justice and peace in the world

The first part of the sentence makes the claim that, collectively, human beings can be seen as a single unity. The metaphor is that of a family. A family is conceptualised as people of different generations, social statuses (adults and children; females and males, for example) and possibly different locations, having a common bond of believing that they are related. The metaphor extends this conception to all human beings. The assertion is that it is possible to create a belief in and feeling of a common bond that relates any human being to any other. 
It enables the possibility of choosing an alternative perspective to that which privileges national solidarities over all others.

The Indian concept of Vasudhaiva Kutumbakam meaning World is Family is a eosmopolitan perspective dating back five thousand years (Chaurasia, 2000: iii).

Cosmopolitanism is also the basis of theistic religions, where humans are seen as descended from a single ancestral couple, such as Adam and Eve, or alternatively as sons and daughters of a holy father God. The same vision also underpins the humanist, non-religious tradition. For example the pre-war Humanist Manifesto, signed by 30 eminent humanists, including John Dewey, is based on a 'deeper appreciation of brotherhood' (American Humanist Association, 1933). Behind the masculine expression is an attempt to define an essential humanity as family. The phrase 'spirit of brotherhood' is also included in Article 1 of the UDHR.

Viewing the population of the world as a human family is a cosmopolitan perspective. It engages both the intellect and the emotions. It takes an intellectual leap to conceptualise seven billion human beings as a single family. The concept of family implies a feeling of belonging, indeed probably a pride in being part of this community in all its diversity and with its histories, cultures and achievements. A cosmopolitan perspective includes a global perspective that transcends borders. It does not necessarily ignore more local belongings including the national dimension. The claim made by the UDHR is that all human beings are entitled to be treated with dignity. This is said to be inherent, that is, dignity is the essence of what it is to be human. With entitlement to dignity and recognition as a member of the human family comes entitlement to rights. An entitlement is a strong claim. Claims to human rights are inalienable. They cannot be taken away or denied. The agents of the state, such as the 
police, may fail to treat someone with dignity (moving prisoners in cattle trucks, to take an example from the Nazi period), but we may judge such actions to be barbarous and amoral, since although the actions may have been lawful, they are based on removing the status of human being, since they remove the dignity of the person.

A further principle of the UDHR is that human beings have a strong claim to equality in rights. This includes the right to be treated with dignity by all other human beings including particularly the agents of the state. The basis of this claim is not first and foremost legal. It is a moral claim. It assumes that with recognition of humanity and of dignity for oneself comes a moral responsibility to extend that recognition to all others. Many of the rights and principles of the UDHR were at the time of its drafting and subsequently enshrined in the laws and constitutions of member states of the United Nations. The innovation that was commitment to human rights lay in the proposal of a single set of fundamental principles and norms intended to inform the laws and constitutions of all states.

As it looks back to the abuses of the past, the preamble to the UDHR simultaneously looks to the future. The first paragraph of the preamble to the Declaration is essentially a prediction. It makes the claim that universal respect for human rights will constitute 'the foundation of freedom, justice and peace in the world'. The UDHR is therefore a challenge and an agenda for action. The challenge is to ensure universal respect for human rights for this, it is claimed, will bring about justice and peace in the world. Hence the agenda, strongly taken up by NGOs, is to identify human rights abuses and discriminations in rights and address them.

The assertion that respect for human rights will lead to world peace is perhaps the greatest of the 'large and unsubstantiated claims' made in the UDHR (Freeman, 2002: 10). Such claims can always be challenged, but it is in the nature of moral, religious, ideological and philosophical systems and agendas that in the end they are articles of faith and belief. 
The Declaration situates its authority in terms similar to those of popular sovereignty. The proposed vision is said to represent 'the highest aspiration of the common people'. However, simultaneously, the authority of the UDHR is shown to lie in its acceptance by the governments of member states:

Member States have pledged themselves to achieve, in cooperation with the United Nations, the promotion of universal respect for and observance of human rights and fundamental freedoms (preamble).

Whilst member states that support the UDHR also accept that human rights should be protected by the rule of law, the Declaration is a source of law but it is not in itself law. States respectful of human rights voluntarily constrain their agents from using the maximum violence of which in theory they have a monopoly.

\section{Human rights and the four freedoms}

Following the reference back to the 'barbarous acts' the preamble sets out a vision of the future in utopian terms:

the advent of a world in which human beings shall enjoy freedom of speech and belief and freedom from fear and want has been proclaimed as the highest aspiration of the common people

This section incorporates ideas set out in a speech by US President Franklin J Roosevelt as he addressed Congress on 6 January 1941 following his election to a third term of office. His four freedoms come as two pairs. Freedom of speech and belief are sometimes defined as negative freedoms since it is argued that they simply require inaction by government. The freedoms are asserted in opposition to interference from authority. They demand 'the subjection of power to the reason of law' (Douzinas, 2000: 5). They are amongst the civil and political rights essential for any form of democracy and political activity. 
Although freedom of belief is frequently associated with religious persecution, it applies just as much to political beliefs.

The two other freedoms are freedoms 'from'. The first is the psychological freedom from fear. This is the right of citizens and others living in the state to security, guaranteed through a system of policing and laws. Freedom from want is the right of access to basic standards of nutrition, health care, income and shelter. Without these, human beings are deprived of their capacity to develop their capabilities and thus effectively robbed of their dignity and personal liberty (Sen, 1999).

Freedoms are the essence of human rights. This being the case, it is not surprising that most of the articles of the UDHR defend and promote freedoms. Thinking of the rights of the UDHR in relation to the freedoms they promote can act as a mnemonic. It is a way of remembering the extent of but also the limitation of the rights guaranteed in the 30 articles of the UDHR (Osler \& Starkey, 2010).

Freedoms are not absolute. French critics of liberal economic theories have frequently used the expression 'the free fox in the free henhouse' (see for example De Coster $\&$ Pichault, 1998: 120). Where there are no constraints but an imbalance of power, the advantage is always with the powerful. The power relation is of the essence. A human rights perspective balances freedoms with a concern for equality of access to rights. Freedoms are exercised in society and claiming them is constrained by the acceptance of the principle that all other human beings can claim the same right.

Struggles for self-expression are an essential element of what it means to be human. Freedom of speech is also a political right and it extends to rights to publish and use the media. These are truly fundamental freedoms that have been the subject of struggle for centuries. People with religious, political and philosophical views that challenge authority 
have historically used their ingenuity and their capacity to organize to claim their rights of expression.

Although these freedoms appear to require simply an absence of repression or censorship, in fact, upholding them can be costly. Modern liberal democratic states are required to put in place laws, institutions and mechanisms to protect citizens from the abuse of freedom of expression such as hate speech and to ensure that political processes enable minorities to be heard, for example.

The UDHR can be read as a direct reaction to the use of the law by the Nazi state. Within a month of coming to power in Germany in early 1933, Hitler revoked the section of the Weimar constitution that guaranteed personal liberty. He over-rode previous legal protection to allow agents of the state to restrict personal liberty, freedom of expression, freedom of the press, and freedom of assembly and association. Privacy laws were also ignored so that state agents could intercept postal and telephone communications, search houses and confiscate property. Proclaimed in the immediate aftermath of the Reichstag fire, Hitler's decree was seen as aimed at Communists and therefore had a measure of popular support. However, once in place it was effortlessly extended to others depicted as enemies of the state. The abolition of the right to personal liberty enabled the state to detain political enemies under so-called protective custody without requiring the involvement of the police or the courts (Kershaw, 1995).

Citizens need to be aware that their freedoms are not absolute and that the state may at any time attempt to limit the freedoms of citizens, typically in the name of security and stability. By defining entitlements to specific freedoms, the UDHR provides the legal and political discourse that citizens can use to gain support for campaigns against repressive activity and to argue their case where there is a possibility of dialogue with government. The next sections analyse the UDHR through the lens of the four freedoms. They suggest some of 
the key implications of accepting these rights as normative standards as well as some of the tensions and contradictions that may arise when rights are asserted.

\section{Freedom of speech and belief in the UDHR}

Article 12 guarantees respect for privacy. This is essentially freedom from the intervention of the state in private communications and correspondence, including monitoring of telephones and electronic communications. This article also guarantees the protection of the law against slander and defamation.

Article 18 guarantees freedom of thought, conscience and religion. This article is essentially about religious freedom. It includes the right to practice or manifest religious beliefs, for example by wearing clothes or symbols of a particular religion. It also includes the right to change religion, in other words freedom from coercion to join or remain in a particular faith community.

Freedom of opinion and expression in article 19 includes a right to disseminate and receive information through any media regardless of frontiers. This requires that states refrain from exercising censorship of the media or blocking access to radio or television broadcasts or internet sites. These and all other freedoms are liable to be limited under article $29 \mathrm{~b}$ by permissible laws that are enacted in order to protect the equal rights of others and meet 'the just requirements of morality, public order and the general welfare in a democratic society'. In order to limit the freedoms of speech and belief, governments often first enact legislation, which, in a democracy, entails debate and compromise. From a human rights perspective, governments must also defend or be prepared to modify their legal frameworks in cases where there is a reasonable claim that restrictions on the freedoms are too severe. The principle for judging any legislation is codified in $29 \mathrm{~b}$ as 'the general welfare'. Thus 
governments may be entirely justified in restricting freedoms to trade in images of child abuse or to engage in organized crimes including people trafficking.

Other rights associated with freedom of speech and belief are the freedom of peaceful assembly and association in article 20 and the right to a democratic process of government in article 21. Peaceful assembly and association are essential for the formation and running of political parties and pressure groups. This is a fundamental political freedom. However, article 20 is also a guarantee against coercion, so that no one can be forced to join an association. Here again, individual freedom is the principle, but it is always within a social context.

The right to education, article 26, opens up all other rights since a right is only a right when you are aware of it. Article 27 is the right to participate in cultural life which must itself be considered in a human rights perspective. Cultures that deny or fail to respect human rights, such as political groups espousing terrorism or religious groups coercing people into membership of cults, can and should face restrictions to ensure that they conform to normative human rights principles.

Although there are many ways in which democratic principles can be translated into institutions and processes, the right to a democratic process is a right in itself and, as article 29 makes clear is also the context for all other rights. In other words the vision of freedom justice and peace is also a vision of continuous democratization, whether in established or emerging democratic states. The World Conference on Human Rights in Vienna in 1993 proclaimed democracy, development and human rights to be 'interdependent and mutually reinforcing' (UNHCR, 1994: 195). This also implies that democracy is not a steady state but a dynamic process of enabling people to live together with a sense of security and justice. This is what John Dewey ([1916] 2002: 101) called 'more than a form of government: it is 
primarily a mode of associated living, of conjoint communicated experience'. It is this understanding of democracy that is most relevant to schools and education systems.

However, as Freeman (2002) points out, human rights and democracy have independent and potentially competing theoretical foundations. Democracy is a political construct based on the premise that the people should rule. Human rights is a moral and legal concept that provides a set of principles against which the performance of governments should be judged. They therefore aim to challenge the power of governments since even those democratically elected may overturn human rights, as in the case of the first Nazi government quoted above. Whilst democratic theory gives power to elected representatives, human rights theory limits this power and looks also to judges, courts and popular mobilisation as agencies providing checks and balances in the defence of individual freedoms. Article 20 specifically asserts the right of access to public service. This is in reaction to such rights being denied to groups in Nazi Germany.

\section{Freedom from fear}

Freedom from fear is linked closely to freedom of speech and belief. Numerous articles attempt to guarantee freedom from fear of the arbitrary use of power by the state. At the most basic this means the right to life (article 3 ) but this is reinforced by two absolute rights namely freedom from slavery (article 4) and from torture (article 5). Freedom from fear can be mitigated where there is a judicial system that is seen to be fair and to be based on standard procedures. These include recognition as a person before the law (article 6), equal protection by law (article 7), no arbitrary arrest, detention or exile (article 9), a fair, public trial (article 10), presumed innocence and no retroactive laws (article 11). Where individuals suffer extreme state persecution they may claim asylum in another state (article 14). 
Essentially these are the rights to protection from arbitrary and cruel actions by the agents of the state. Individuals and groups should be able to go about their lawful and peaceful business, including participation in political, trades union and cultural activities without fearing unjustified arrest, detention or exile (article 9). They may own property and this is not subject to confiscation by the state (article 17). When arrested, there should be a due legal process which starts by their recognition as a person before the law (article 6), where they are guaranteed equal treatment by the law (article 7). Trials should be held in public and be conducted fairly (article 10). There must be a presumption of innocence unless proven otherwise and no one can be convicted for something that, at the time of the supposed offence was not illegal (article 11).

Freedom from fear is also protected by international law and the international human rights regime (article 28). Articles 29 and 30 assert both limitations to rights and the indivisibility of human rights by outlawing the use of the freedoms guaranteed to undermine human rights or act counter to the spirit of the UN Charter. Article 28 reminds individuals of their responsibilities to their communities. It stresses that human rights are guaranteed by people acting in solidarity with others and recognising that society depends on reciprocity. Although it invokes a sense of duty to the community, such duties are undertaken by a sense of moral conviction rather than by state coercion. Indeed there is no specific codification of human duties since the reciprocal nature of rights, requiring limiting some rights for the protection of the rights of others, is itself a normative principle (Douzinas, 2000).

Struggles for freedoms strongly inform understandings of human rights as struggles for self-realisation, fulfilment and creativity. The UDHR is an inspirational document that has been described as an 'open text, whose reference is past conflict and whose performance will help to decide future struggles' (Douzinas, 2000: 95). 


\section{Freedom from want}

The articles promoting freedom from want are intended to ensure that human beings have sufficient material resources and protection to enable them to access their fundamental human rights. Extreme poverty denies access to life to health and often to education and participation. The main rights are defined in articles 22-25. Article 22 is the right to social security and economic, social and cultural rights. Article 23 is the right to work and fair pay whilst article 24 is the equally important right to rest and leisure. The provision of these rights should help to ensure the guarantee of article 25 namely the right to an adequate healthy standard of living.

These rights are sometimes referred to as second generation or second wave rights, based on the concept of dignity (Klug, 2000). The freedom of speech and belief rights reflect the successful outcome in parts of Europe and the USA by the end of the eighteenth century of campaigns against political oppression and censorship that had been ongoing from earlier centuries. Freedom from rights were conceptualised in relation to struggles for fair conditions at work and for social security which became more intense in the nineteenth and twentieth centuries with the development of political parties and trades unions engaging in emancipatory politics (Giddens, 1990).

In a global perspective access to these 'freedom from' rights is often characterised as development. In this context there is frequently acceptance that the extent to which governments can guarantee them is limited by fiscal resources. This perspective would be more convincing if the more powerful economies would address issues such as terms of trade whereby they have historically exploited particularly former colonies. It is also more persuasive where the extent of government corruption is limited. In fact the Vienna Declaration of the World Conference on Human Rights is quite specific in asserting that: 
While development facilitates the enjoyment of all human rights, the lack of development may not be invoked to justify the abridgement of internationally recognised human rights (UNHCR, 1994: 197).

This powerful message to authoritarian and undemocratic regimes did not in itself result in changes. It did however, along with other statements from the United Nations provide validation for struggles against such regimes that resulted in a number of successful changes towards more democratic political systems across the world.

\section{Conclusion}

Education is about both socialising and liberating. Its functions include transmitting societal norms and initiating into official ways of reading the world. Simultaneously education promotes critical thinking, imagination and capabilities, particularly the capacity to construct multiple identities and subjectivities. Education requires both normative standards and utopian vision. Citizenship education is a space where normative expectations can be learnt and the possibilities offered by utopian imagining can be explored through democratic dialogue. The central place of human rights within citizenship education is promoted by the Council of Europe through its Charter of Education for Democratic Citizenship/ Human Rights Education (EDC/HRE) (Council of Europe, 2010).

Utopian perspectives can easily be obscured by equally powerful visions that include the drive for standards and commitments to parental choice of schools. However, governments, as well as educators, persist in identifying schools as instruments of policy to address major social and political issues. For instanced there is an expectation that schools address and help young people to understand global issues including climate change, resource depletion and the world financial system. Issues of globalisation require and 
understanding of principles on which there is the widest possible global consensus, namely human rights and fundamental freedoms.

Whilst leaders may assert the failure of multiculturalism, they nonetheless expect schools to function as places for learning to live together. Schools are often at the forefront of struggles for recognition by minorities that may find expression in demands to accept outward symbols of religious or ethnocultural identity, for example. Responding to such issues requires a confident expression of the principles on which teachers and school authorities will act. When clashes of values are framed as human rights issues, freedoms are contexualised within school systems that are required to also consider equality issues as well as the protection of the vulnerable.

However, cosmopolitan citizenship education with a utopian vision has the potential to challenge existing structures whether of the school or of wider society. It is a programme that cannot guarantee control of its outcomes. The essence of human rights is freedom or liberation defined within a social and democratic context. The implications of adopting such an approach are a possible loss of control. The implications of not adopting such an approach may be that young people remain apathetic or that they become tempted by alternative major utopias. 


\section{REFERENCES}

Anderson-Gold, S. (2001). Cosmopolitanism and Human Rights. Cardiff: University of Wales Press.

Banks, J. A., Mcgee Banks, C. A., Cortes, C. E., Hahn, C., Merryfield, M., Moodley, K. A., Murphy-Shigematsu, S., Osler, A., Park, C. \& Parker, W. C. (2005). Democracy and diversity: Principles and concepts for educating citizens in a global age. Seattle, WA: Center for Multicultural Education, University of Washington.

Beiner, R. (Ed.). (1995). Theorizing Citizenship. Albany: State University of New York Press.

Bonnell, J., Copestake, P., Kerr, D., Passy, R., Reed, C., Salter, R., et al. (2011). Teaching approaches that help to build resilience to extremism among young people [Research Report DFE-RR119]. London: Department for Education.

Conservative Party. (2010). Invitation to Join the Government of Britain. Conservative Manifesto 2010. London: Author.

Council of Europe. (2010). Recommendation CM/Rec(2010)7 of the Committee of Ministers to member states on the Council of Europe Charter on Education for Democratic Citizenship and Human Rights Education

De Coster, M., \& Pichault, F. (Eds.). (1998). Traité de sociologie du travail (2nd edition). Brussels: De Boeck.

Delors, J. (1996). Learning: the treasure within. Paris: UNESCO.

Department for Education and Skills. (2005). Developing the global dimension in the school curriculum. London: DfES with DfID.

Department for Education and Skills. (2007). Diversity and Citizenship: curriculum review (Ajegbo review). London: DfES

Dewey, J. ([1916] 2002). Democracy and Education: an introduction to the philosophy of education. In S. J. Maxcy (Ed.), John Dewey and American Education Vol. 3. Bristol: Thoemmes.

Donnelly, J. (2003). Universal Human Rights in Theory and Practice (2nd edition). Ithaca and London: Cornell University Press.

Douzinas, C. (2000). The End of Human Rights: critical legal thought at the turn of the century. Oxford: Hart.

Freeman, M. (2002). Human Rights: an interdisciplinary approach. Cambridge: Polity.

Giddens, A. (1990). The consequences of modernity. Cambridge: Polity.

Goodwin, M. (2011). Right Response: understanding and countering populist extremism in Europe. London: Chatham House. 
Group of Eminent Persons. (2011). Living Together: combining diversity and freedom in 21st-century Europe. Strasbourg: Council of Europe.

Halpin, D. (2003). Hope and Education: the role of the utopian imagination. London: RoutledgeFalmer.

Halpin, D. (2006). Understanding Curriculum as Utopian Text. In A. Moore (Ed.), Schooling, Society and Curriculum (pp. 147-157). London: Routledge.

Home Office. (1999). Stephen Lawrence inquiry: Home Secretary's action plan. London: Home Office.

Home Office. (2001). Community Cohesion: A Report of the Independent Review Team [Cantle Report]. London: Home Office.

Huntington, S. (1996). The Clash of Civilizations and the Remaking of World Order. New York: Simon \& Schuster.

Kaldor, M. (2003). American power: from 'compellance' to cosmopolitanism? International Affairs, 79(1), 1-22.

Kerr, D. (1999). Changing the political culture: the Advisory Group of Education of Citizenship and the Teaching of Democracy in Schools. Oxford Review of Education, 25(1\&2), 275-284.

Kershaw, I. (1995). The Extinction of Human Rights in Nazi Germany. In O. Hufton (Ed.), Historical Change and Human Rights: the Oxford Amnesty Lectures 1994. New York: Basic Books.

Klug, F. (2000). Values for a Godless Age: the story of the UK's new Bill of Rights. Harmondsworth: Penguin.

Klug, F. (2011). Briefing Note: deportation and the right to respect for private and family life under Article 8 HRA. London: Human Rights Futures Project, LSE http://www2.lse.ac.uk/humanRights/research/projects/humanRightsFutures.aspx.

Mannheim, K. ([1936] 1991). Ideology and Utopia: An Introduction to the Sociology of Knowledge. London: Routledge.

Osler, A. (2006). New Directions in Citizenship Education: re-conceptualising the curriculum in the context of globalization. In A. Moore (Ed.), Schooling, society and Curriculum (pp. 100-114). London: Routledge.

Osler, A. (2008). Citizenship education and the Ajegbo report: re-imagining a cosmopolitan nation. London Review of Education, 6(1), 9 - 23.

Osler, A., \& Starkey, H. (2005). Study on the Advances in Civic Education in Education Systems: good practices in industrialized countries. In V. Espinola (Ed.), Education for Citizenship and Democracy in a Globalized World: a comparative perspective (pp. 19 - 60). New York: Inter-American Development Bank. 
Osler, A., \& Starkey, H. (2009). Citizenship Education in France and England: contrasting approaches to national identity and diversity, In J. A. Banks (Ed.), The Routledge International Companion to Multicultural Education (pp. 334-347). New York: Routledge.

Osler, A., \& Starkey, H. (2010). Teachers and Human Rights Education. Stoke-on-Trent: Trentham.

Qualifications and Curriculum Authority. (1998). Education for Citizenship and the Teaching of Democracy in Schools: Final Report of the Advisory Group on Citizenship (the Crick Report). London: Qualifications and Curriculum Authority (QCA).

Rawls, J. (1999). The Law of Peoples. Cambridge, MA Harvard University Press.

Ricoeur, P. (1978). Imagination in Discourse and Action. In A.-T. Tymieniecka (Ed.), The Human Being in Action: The Irreducible Element in Man. Part II. Investigations at the Intersection of Philosophy and Psychiatry (pp. 3-22). Dordrecht: Reidel.

Runnymede Trust. (2000). The Future of Multi-Ethnic Britain. The Parekh Report. London: Runnymede Trust.

Sen, A. (1999). Development as Freedom. Oxford: Oxford University Press.

Taylor, C. (1994). The politics of recognition. In A. Gutmann (Ed.), Multiculturalism: examining the politics of recognition. Princeton NJ: Princeton University Press.

Torres, C., \& Teodoro, A. (Eds.). (2007). Critique and Utopia: new developments in the sociology of education in the twenty-first century. Plymouth: Rowman and Littlefield.

Touraine, A. ([1997] 2000). Can we Live Together?: equality and difference Cambridge: Polity.

United Nations General Assembly. (1948). Universal Declaration of Human Rights. New York: United Nations.

United Nations High Commissioner for Refugees (UNHCR). (1994). Human Rights: the new consensus. London: Regency Press.

Wallerstein, I. (1998). Utopistics; Or Historical Choices in the Twenty-First Century. New York: New Press.

Webb, D. (2009). Where's the vision? The concept of utopia in contemporary educational theory. Oxford Review of Education, 35( 6 ), 743 - 760.

Winter, J. (2006). Dreams of Peace and Freedom: utopian moments in the 20th century. New Haven and London: Yale University Press. 